\title{
CONVERGENCE OF TECHNOLOGIES
}

\author{
R. Siriram \\ School of Mechanical, Industrial and Aeronautical Engineering \\ University of the Witwatersrand, South Africa \\ raj.siriram@mea.dimensiondata.com
}

\begin{abstract}
Technology is a catalyst for competitive advantage. However, it is how technology is used that leads to a firm's improved performance. In this article, an investigative framework is constructed to understand better what strategically drives new technology adoption. The strategic drivers include technology and business strategy alignment, better technology planning and selection of new technologies, the effects on a firm's culture and climate, links to a firm's organisational and environmental evolution, and benefits through convergence and collaboration. Using an investigative framework, it is shown how the strategic drivers link to improve a firm's performance, producing competitive advantage. The investigative framework is tested using structural equation modelling. Various hypotheses are formed, and recommendations for further research are made.
\end{abstract}

\section{OPSOMMING}

Tegnologie is ' $n$ katalisator vir mededingende voordeel. Dit is egter hoe tegnologie aangewend word wat aanleiding gee tot ' $n$ onderneming se verbeterde prestasie. In hierdie artikel word ' $n$ ondersoekende raamwerk gekonstrueer om insig te kry in dit wat die aanvaarding van nuwe tegnologie strategies dryf. Die strategiese dryfvere sluit in die belyning van tegnologie en ondernemingstrategie, beter tegnologiebeplanning en seleksie van nuwe tegnologieë, die effek op ' $n$ onderneming se kultuur en klimaat, koppeling na ' $n$ onderneming se organisatoriese en omgewingsevolusie, en voordele verkry deur konvergensie en samewerking. Deur ' $n$ ondersoekende raamwerk te gebruik, word daar getoon dat die strategiese dryfvere koppel om 'n onderneming se prestasie te verbeter en sodoende ' $n$ mededingende voordeel te skep. Die raamwerk word getoets en hipoteses geformuleer waarna aanbevelings oor verdere navorsing aan die hand gedoen word. 


\section{INTRODUCTION}

We live in a networked society where firms interact with other firms. A multitude of technologies help instantaneous interaction to happen. Technology is used to break down barriers of location and time, and in so doing may lead to better firm performance and competitive advantage. We are moving from an age of physical space to cyberspace [28], beyond the barriers of current technologies (the internet, email, telecommunications, computer networks) towards an era of convergence and collaboration [42]. In the context of this paper, 'convergence' means the merging of different technologies, and 'collaboration' means the instantaneous interaction of firms. As technologies converge and firms collaborate, better opportunities for firms' performance are created.

Technology is seen as a resource to derive competitive advantage [23]. Kohler, Matzler \& Fuller [26] give examples of how communication and information technologies are adding new capabilities to firms. As a result, says Salhieh [40], firms must continually seek new technologies, change according to new trends, and develop strategies to compete. Given the rapid pace of technology growth, Ismail et al. [24] see many market pressures stemming from factors of global competition, a reduction in lead-time, and the life expectancy of products, diversification of demand, and new technologies. Siriram \& Snaddon [43] argue that the business world is flooded with new technologies, where technology is seen as the catalyst initiating the flow of information and knowledge through the firm. Gupta, Czernik \& Sharma [18] say that the benefits derived from new technologies lie in the way the technology is used. As a result of these factors, firms need to be clear about how benefits from newer technologies may be better used to drive competitive advantage.

Ross \& Beath [39] argue that new technologies present firms with opportunities or imperatives to adopt new business models. Friedman [16] sees big improvements in technology coming from the way technology is combined with new ways of doing business. This he sees as the convergence of technology leading to the formation of new business models (such as collaboration). Even though research shows the benefits associated with new technology adoption, Hanna-Kisa, Wikstrom \& Jantunen [21] argue that many managers struggle to adopt and integrate available technologies (either new or mature) into their business; so a better understanding of the factors hampering new technology adoption is necessary. New technology is often hampered by resistance to change, which affects a firm's culture and climate. Cormican \& O'Sullivan [10] see culture and climate as values, norms and beliefs; and these are either an enabler or a barrier to sharing or reusing knowledge. A firm's culture and climate is seen as the firm's ability either to lead or to resist the adoption of new technology. A firm's organisational and environmental evolution, on the other hand, is seen as a critical part of a firm's ability to grow [29]. In addition, Porter [36] defines organisational and environmental evolution as criteria for competitive advantage, including generalised factors like generic technologies that are easy to source, specialised factors like skilled labour and natural resources, related and supporting industries like home-based suppliers, associated demand, the firm's structure, rivalry and competition policies, and large governmen projects. Due to changes in a firm's culture and climate, firms are forced through an organisational and environmental evolution.

The use of technology for competitive advantage is supported by Henderson \& Venkatraman [22] and Luftmann, Lewis \& Oldach [30]. In addition, Bharadwaj [4] relates models on firm performance to technology, while other models relating technology adoption and firm profitability are supported by Stoneman \& Kwon [44]. Using technology to drive better firm performance requires an understanding of key strategic drivers - for example, technology and business strategy alignment, new technology planning and selection, a firm's culture and climate, organisational and environmental evolution, and convergence and collaboration. Against this backdrop, we pose the following two central questions: 
- Does the adoption of new technologies result in changes in a firm's organisational and environmental evolution?

- Do changes in the firm's organisational and environmental evolution lead to better performance?

These strategic drivers, together with the research questions, are discussed next in the literature survey and hypothesis development.

\section{LITERATURE SURVEY AND HYPOTHESIS DEVELOPMENT}

The adoption of technology for competitive advantage has become apparent since the early works of Schumpeter (1934). In addition, Luftmann, Lewis \& Oldach [30] reinforce Schumpeter's view about new technology adoption that it improves wealth (i.e. performance). Supporting this view of technology, Burgelman, Christensen \& Wheelwright [6] see technology as a resource alongside human, financial, and information resources, and as a potential source of distinctive core competence - a resource-based view (RBV) of the firm, which is a subset of dynamic capabilities. Cetindamar \& Phaal [8], Friedman [16], and Teece [45] argue that to manage technology as a distinctive core competence, a technology strategy must be developed. In addition, the technology strategy must support the business strategy. Firms traditionally work in silos, and so there are organisational barriers between sections of the firm. Barriers occur through physical location as well as time (a transactional cost economic (TCE) view of the firm). Barriers create delays and hamper a firm's response to market needs. The firm needs to be viewed beyond the traditional silo barrier approach. This stance is shared by Van de Vrande, De Jong \& Vanhaverbeke [48], who see technology being used as a tool to extend the barriers of the firm, expand research and development capabilities, and extending complementary assets [Teece 45] to other firms; while Chesbrough [9] views this model of expanding the barriers of the firm as an open innovation model, as opposed to the traditional silo closed innovation model.

Building on this view, technology may be used as a distinctive resource to reduce barriers, and improve collaboration within and between firms [48]. More specifically, technology may be used to create networks with other firms, thereby creating opportunities for collaboration and for developing more capabilities [17]. Through collaboration, firms network with other firms, creating collective relationships and efficiencies in productivity [35]. From the RBV of the firm, technology may be treated as a distinctive competence and a source of dynamic capability.

Teece [45] sees the dynamic capabilities of the firm as its ability to integrate, build, and reconfigure internal and external competencies to address rapidly changing internal and external environments. Building on this premise, dynamic capabilities are seen as central to technology management [8]. From this perspective, two issues are raised: (1) Da Silveira [12] says one of the major challenges when considering technological adoption is deciding when to adopt new technology; and (2) Porter [35] alludes to a process of continuous improvement to sustain a competitive position. From these two points it may be argued that a more coherent planning approach to technology adoption will be necessary to obtain the required benefits [33]. This includes careful technology planning and a selection process that may help firms choose the right technologies, leading to better performance. In summary: for firms to improve performance and derive competitive advantage, they should make timely investments in new technologies and continually innovate and upgrade but at the same time collaborate with other firms (i.e. synchronise activities throughout the value chain). The stance taken by Nelson [33] is similar to Porter [35,36], where the focus is on continuous collaboration and improvement throughout the value chain, affecting the firm's organisational and environmental evolution.

Evidence from firms adopting new technologies shows that a firm's performance is dependent on developing abilities to respond faster to customer needs and competitor threats. To understand better how these factors link to better firm performance, an investigative framework is constructed (Figure 1). 


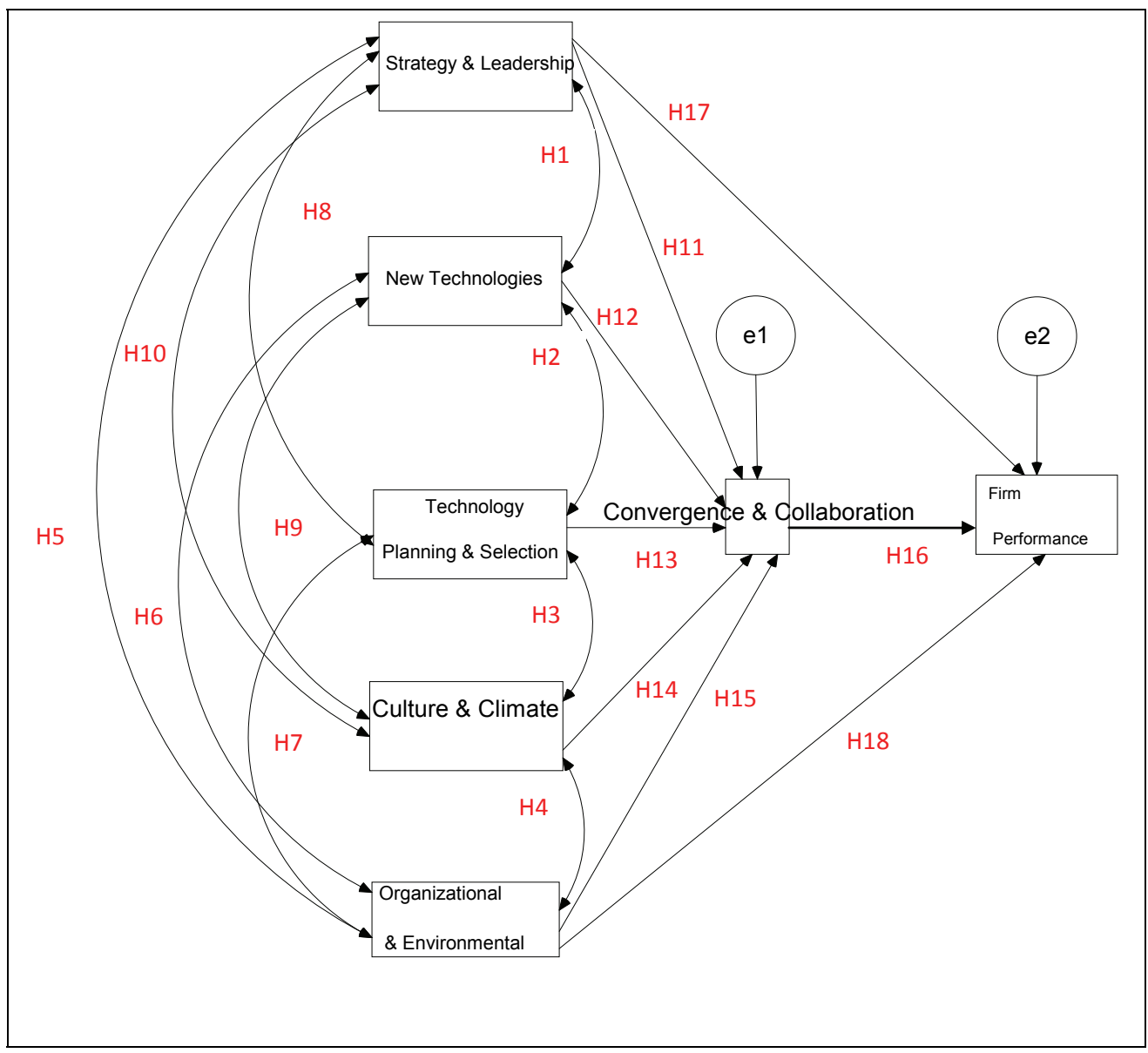

Figure 1: Investigative framework and hypothesis development

The investigative framework may allow a firm to foster a better culture and climate, which may be a catalyst to improving its organisational and environmental evolution. Factors that may contribute to driving organisational change within and between firms include technology and business strategy alignment, new technology planning and selection, culture and climate, organisational and environmental evolution, and convergence and collaboration. The investigative framework (Figure 1) and each of the strategic drivers are discussed next.

\subsection{Strategic drivers}

Radas \& Bozic [38] propose a well-defined strategic process to improve innovation and growth. They say that a well-defined corporate strategy and sound management practices and organisational structures are important enablers of innovation (citing Birchall, Chanaron \& Soderquist [3]), while their absence can seriously undermine growth (citing Freel [15] and Kaufmann \& Todtling [25]). Developing a competitive strategy in terms of new technology adoption requires technology and business alignment, as well as an alignment of strategic drivers.

Firms are seen to be interconnected with other firms; and this interconnection leads to better performance and competitive advantage [37]. More importantly, Porter [37] shows how interconnected firms (clusters) enable innovation and speed up productivity growth. Regardless of the choice of technology, firms must attempt to link technology strategy with 
business strategy ([34], [51], [13]). In addition, Mitarai [32] and Sams [41] show how successful adoption of new technologies leads to other benefits relating to convergence and collaboration. Therefore a strategic planning process is necessary to link technology and business strategy. Carr \& Pearson [7] define strategic planning as the process of planning, evaluating, implementing, and controlling a firm's strategies. In this study, technology strategy is seen as the process of planning, evaluating, implementing, and controlling strategic and operating decisions about the technology planning and selection needs of the firm. So it is suggested that linking technology strategy and business strategy has a positive impact on a firm's need for new technologies, and therefore demands more refined technology planning and selection processes. The following hypotheses are formed.

- H1: Strategy and leadership has a positive impact on a firm's ability to adopt new technologies.

- H2: A firm's need for the adoption of new technologies has an impact on the firm's technology planning and selection process.

\subsection{Strategy and new technology adoption}

Technology adoption is open to many different technology choices. Nelson [33] argues that some technologies are winners, and some are losers; therefore choosing the right technology is crucial for implementing a long-term technology strategy. Firms investing in new technologies may adopt a piecemeal strategy, thereby creating risks associated with disintegrated technologies. So having a long-term technology planning and selection process is crucial to supporting the technology and business strategy. It may be argued that firms that adopt a defined technology planning and selection process are better positioned to create an environment that allows better fostering of their culture and climate. Cormican \& O'Sullivan [10] define a firm's 'culture' as being the values, norms, and beliefs; and 'climate' as the policies, practices, and procedures. They see culture and climate as both an enabler and a barrier to sharing knowledge or innovation. So culture and climate may be seen as a factor when considering a new technologies strategy and adoption. New technology adoption is often accompanied by resistance to change, affecting a firm's culture and climate and its organisational and environmental evolution. So having the right structure is necessary to support a firm's culture and climate and its organisational and environmental evolution. A careful technology planning and selection process is advised, to mitigate the risks associated with the adoption of new technologies, taking into consideration the firm's culture and climate and organisational and environmental evolution.

The following hypotheses are formed next:

- H3: A firm's technology planning and selection process positively affects its culture and climate.

- H4: A firm's culture and climate positively affects its organisational and environmental evolution.

A better culture and climate and organisational and environmental evolution have a positive impact on a firm's ability to deliver on its strategy and leadership, evolve with the new technologies, and develop a culture and climate conducive to technology adoption.

The following hypotheses are formed next:

- H5: Organisational and environmental evolution has a positive impact on a firm's strategy and leadership.

- H6: Organisational and environmental evolution has a positive effect on a firm's ability to adopt new technologies.

- H7: Organisational and environmental evolution has a positive effect on a firm's technology planning and selection process. 
- H8: A firm's technology planning and selection process positively impacts its strategy and leadership.

- H9: A firm's need for new technologies positively affects its culture and climate.

- H10: Strategy and leadership positively affects a firm's culture and climate.

\subsection{Convergence and collaboration}

Due to the investment in new technologies, firms are more likely to invest in better technology planning and selection processes - and to pay more attention to culture and climate. An improved culture and climate will improve the adoption of new technologies, and also may be a catalyst for other innovative ideas within the firm. This in turn may lead to an improvement in a firm's organisational and environmental evolution. This scenario is supported by Porter [37], who argues that "upgrading is the process of shifting advantages throughout the value chain to more sophisticated types and employing higher levels of skill and technology". Through upgrading, firms may adopt new technologies, which may allow them to improve their technology adoption, thus creating the opportunity for technology convergence. This convergence may allow firms to collaborate better with other firms.

Learning from the banking industry [18] shows how successful banks will align business processes to market needs and use technology to execute processes. Gupta, Czernik \& Sharma [18] postulate that banks will become more entrepreneurial, providing easy-to-use electronic funds, which will be enhanced by the next generation of electronic delivery systems, which will include technologies fully interfaced into a nationwide network with other banks, sharing costs while also sharing in the benefits. This is a classic example of banks collaborating as a result of new technologies, so becomin more competitive. Therefore the following hypotheses are formed:

- H11: A firm's strategy and leadership positively affects its ability to converge and collaborate.

- H12: A firm's adoption of new technology positively affects its ability to converge and collaborate.

- H13: A firm's technology planning and selection process positively affects its ability to converge and collaborate.

- H14: A firm's culture and climate positively affects its ability to converge and collaborate.

- H15: A firm's organisational and environmental evolution positively affects its ability to converge and collaborate.

The firm's ability to adopt new technologies creates opportunities to continually innovate, thus leading to further technology and business alignment and driving performance. Links to a firm's performance are discussed next.

\subsection{Drivers for a firm's performance}

Hanna-Kisa, Wikstrom \& Jantunen [21] and Teece, Pisano \& Sheun [46] argue that developing a firm's capabilities (i.e. dynamic capabilities, as in technological skills, and distinctive core competencies [6]) may enable firms to react to market and technological needs; while in other cases, not developing capabilities might constrain the firm from reacting to market changes and adapting to the environment. Therefore developing the capabilities to drive a firm's performance may lead to benefits in its performance. Many of the capabilities quoted in the research are from the manufacturing industry; however, some researchers have drawn parallels between the manufacturing industry and related industries. Linton [29] shows experiences from the manufacturing industry being incorporated into service industries using examples from the ICT industry. Kettunen [27] offers other learnings from the manufacturing industry, drawing parallels between agile manufacturing and software development. Carr \& Pearson [7] cite Walker and Poppo (1991, p. 499), showing how adoption of advanced manufacturing technologies (AMTs) led to better performance. Further evidence is given by Boyer, Ward \& Leong [5], who show the 
advantages of AMTs such as extreme flexibility, rapid response to changes in demand and product design, greater control and repeatability of processes, reduced waste, faster throughput, and distributed processing capability. Similarly, it is proposed that convergence and collaboration may lead to benefits in efficiency and scope, reduction of waste, etc. Learning from the AMT industry, parallels can be drawn with the ICT industry; and so we hypothesise that convergence and collaboration have a positive effect on a firm's performance.

- H16: A firm's convergence and collaborative ability has a positive effect on its performance.

- H17: A firm's strategic leadership has a positive effect on its performance.

- H18: A firm's organisational and environmental evolution has a positive effect on its performance.

This paper proposes exploratory research in the area of new technology adoption, which may lead to better performance, giving rise to competitive advantage.

\section{RESEARCH METHODOLOGY}

The research consisted of a survey process. The research instrument was developed through an extensive literature survey. The industries selected included electronics and electrical, information and communications technology, fast moving consumer goods (FMCG), logistics, and financial industries. Firms participating in the research were selectively chosen from lists of germane publications. Firms operating within South Africa were included in the analysis. The following germane publications and organisations were used for the selection: Fortune (March 2007 edition, no. 4), Instrument and Control magazine (March 2007 edition), Financial Mail top 100 firms, top technology companies in Southern Africa, and the top information and communication technology (ICT) firms in South Africa, and the Institute of Industrial Engineering South African Chapter. The methodology used to select the industry categories has been used elsewhere [43]. This resulted in a total sample size of 585 firms. Given previous research evidence by Stoneman \& Kwon [44], the sample sizes were considered to be adequate. The literature review focused on the areas of technology, strategic purchasing, operations management, and strategic management. The instrument consisted of 36 questions, all of which were used in the final study after testing. The majority of the questions consisted of 7-point Likert scales, and some forced ranking questions were also used. The responses ranged from 1-7, and in each case 1-7 was defined. The response ' $X=$ Not relevant/Do not know' was also made available.

The pre-test consisted of a sample of 15 respondents who were selected to test the overall clarity, structure, relevance, and wording. The pre-test was then followed up by a pilot test, which consisted of a sample size of 32. Cronbach alpha tests were performed for the pilot group. Cronbach alpha values below 0.728 were removed from the analysis. The instrument was modified and distributed to the main group. The normal procedures for exploratory type research were followed - i.e. initial electronic contact was made through email, thereafter the instrument was made available through a website, which included a document summarising the objectives of the research. During this research the electronic website largely improved the facilitation of responses. Several follow-up personalised emails were sent over a two month period. In total 142 responses were received - a response rate of $24.27 \%$. To ensure that the managers who responded did not differ substantially from those who did, we tested non-response bias by comparing early respondents with late respondents. The rationale behind this comparison was that late respondents show a greater resemblance to non-respondents than early respondents. The 'means' of several constructs were compared, and $t$-tests revealed no significant differences between the two groups, suggesting that non-response is not a major factor [1]. Table 1 shows the profile of the research sample. The research results are discussed next. 


\section{RESEARCH RESULTS}

\subsection{The measurement model}

Confirmatory factor analysis (CFA) was conducted to check the reliability and validity of the model. The Cronbach alpha ranges from 0.728 to 0.858 for 7 constructs, indicating a high internal consistency. In addition, all the average variances extracted are above the recommended 50\% (0.5) [19]. A summary of the reliability tests is shown in Table 2.

\begin{tabular}{|c|c|c|}
\hline Respondent Characteristics & $\begin{array}{l}\text { Number of } \\
\text { respondents who } \\
\text { answer }(n=142)\end{array}$ & Percentage (\%) \\
\hline \multicolumn{3}{|l|}{ Position in company } \\
\hline 1. Chairman/CEO/COO. & 25 & $17.61 \%$ \\
\hline 2. Executive directors. & 22 & $15.49 \%$ \\
\hline 3. Non executive directors/General managers. & 45 & $31.69 \%$ \\
\hline \multirow[t]{2}{*}{ 4. Others e.g. Middle managers, etc } & 50 & $35.21 \%$ \\
\hline & 142 & \\
\hline \multicolumn{3}{|l|}{ Firm categories } \\
\hline 1. National local company. & 52 & $36.62 \%$ \\
\hline 2. Multi national company. & 59 & $41.55 \%$ \\
\hline 3. Joint venture, mergers or strategic alliance. & 24 & $16.90 \%$ \\
\hline \multirow[t]{2}{*}{ 4. Other e.g. Franchises. } & 7 & $4.93 \%$ \\
\hline & 142 & \\
\hline \multicolumn{3}{|l|}{ Education } \\
\hline 1. High school & 38 & $26.76 \%$ \\
\hline 2. Bachelor's & 52 & $36.62 \%$ \\
\hline 3. Postgraduate & 25 & $17.61 \%$ \\
\hline \multirow[t]{2}{*}{ 4. Other e.g. Colleges, technical colleges } & 27 & $19.01 \%$ \\
\hline & 142 & \\
\hline \multicolumn{3}{|l|}{ Industry categories } \\
\hline 1. Electronics and Electrical engineering. & 30 & $21.13 \%$ \\
\hline 2. Information Technology industry. & 46 & $32.39 \%$ \\
\hline 3. Logistics. & 5 & $3.52 \%$ \\
\hline 4. Financial. & 9 & $6.34 \%$ \\
\hline 5. Fast moving consumer goods & 21 & $14.79 \%$ \\
\hline \multirow[t]{2}{*}{ 6. Other e.g. Resources, Mining, Pharmaceutical } & 31 & $21.83 \%$ \\
\hline & 142 & \\
\hline \multicolumn{3}{|l|}{ Firm size } \\
\hline Less than 100 & 14 & $9.86 \%$ \\
\hline $100-2000$ & 30 & $21.13 \%$ \\
\hline $2001-5000$ & 16 & $11.27 \%$ \\
\hline $5001-10000$ & 33 & $23.24 \%$ \\
\hline $10001-50000$ & 27 & $19.01 \%$ \\
\hline \multirow[t]{2}{*}{ More than 50001} & 22 & $15.49 \%$ \\
\hline & 142 & \\
\hline
\end{tabular}

Table1: Profile of research sample 


\begin{tabular}{|c|c|c|c|c|c|c|c|c|}
\hline$\underset{\tilde{g}}{\tilde{\partial}}$ & 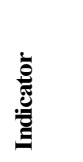 & $\sum^{\bar{g}}$ & 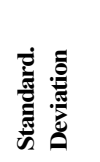 & 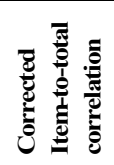 & 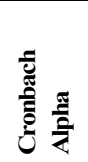 & 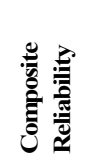 & 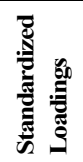 & 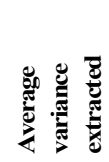 \\
\hline $\begin{array}{l}\text { Strategy and } \\
\text { Leadership }\end{array}$ & $\begin{array}{l}\text { SL5 } \\
\text { SL4 } \\
\text { SL3 } \\
\text { SL2 } \\
\text { SL1 }\end{array}$ & $\begin{array}{l}5.143 \\
4.855 \\
5.250 \\
4.881 \\
4.938\end{array}$ & $\begin{array}{l}1.4666 \\
1.2792 \\
1.2464 \\
1.2820 \\
1.1938\end{array}$ & $\begin{array}{l}0.628 \\
0.605 \\
0.674 \\
0.676 \\
0.676\end{array}$ & 0.834 & 0.971 & $\begin{array}{l}0.762 \\
0.765 \\
0.812 \\
0.788 \\
0.863\end{array}$ & 0.873 \\
\hline $\begin{array}{l}\text { Newer } \\
\text { Technologies }\end{array}$ & $\begin{array}{l}\text { NT3 } \\
\text { NT2 } \\
\text { NT1 }\end{array}$ & $\begin{array}{l}4.569 \\
4.269 \\
4.657\end{array}$ & $\begin{array}{l}1.4439 \\
1.4888 \\
1.5202\end{array}$ & $\begin{array}{l}0.743 \\
0.708 \\
0.562\end{array}$ & 0.816 & 0.95 & $\begin{array}{l}0.843 \\
0.802 \\
0.801\end{array}$ & 0.871 \\
\hline $\begin{array}{l}\text { Planning and } \\
\text { Selection }\end{array}$ & $\begin{array}{l}\text { PS4 } \\
\text { PS3 } \\
\text { PS2 } \\
\text { PS1 }\end{array}$ & $\begin{array}{l}4.886 \\
4.957 \\
4.942 \\
4.343 \\
\end{array}$ & $\begin{array}{l}1.5725 \\
1.3881 \\
1.2292 \\
1.5573 \\
\end{array}$ & $\begin{array}{l}0.676 \\
0.407 \\
0.509 \\
0.503 \\
\end{array}$ & 0.728 & 0.970 & $\begin{array}{l}0.802 \\
0.840 \\
0.791 \\
0.817 \\
\end{array}$ & 0.888 \\
\hline $\begin{array}{l}\text { Culture and } \\
\text { Climate }\end{array}$ & $\begin{array}{l}\mathrm{CC} 5 \\
\mathrm{CC} 4 \\
\mathrm{CC} 3 \\
\mathrm{CC} 2 \\
\mathrm{CC} 1\end{array}$ & $\begin{array}{l}4.797 \\
4.453 \\
4.319 \\
4.514 \\
4.929\end{array}$ & $\begin{array}{l}1.440 \\
1.4534 \\
1.4687 \\
1.2620 \\
1.5054\end{array}$ & $\begin{array}{l}0.657 \\
0.636 \\
0.694 \\
0.741 \\
0.653\end{array}$ & 0.858 & 0.972 & $\begin{array}{l}0.885 \\
0.814 \\
0.783 \\
0.855 \\
0.804\end{array}$ & 0.872 \\
\hline $\begin{array}{l}\text { Organizational } \\
\text { and } \\
\text { Environmental } \\
\text { Effects }\end{array}$ & $\begin{array}{l}\text { OE7 } \\
\text { OE6 } \\
\text { OE5 } \\
\text { OE4 } \\
\text { OE3 } \\
\text { OE2 } \\
\text { OE1 }\end{array}$ & $\begin{array}{l}4.070 \\
5.565 \\
4.531 \\
5.045 \\
4.529 \\
4.794 \\
4.433\end{array}$ & $\begin{array}{l}1.5753 \\
1.2128 \\
1.1828 \\
1.1011 \\
1.3910 \\
1.4198 \\
1.3874\end{array}$ & $\begin{array}{l}0.318 \\
0.391 \\
0.662 \\
0.524 \\
0.408 \\
0.572 \\
0.398 \\
\end{array}$ & 0.742 & 0.980 & $\begin{array}{l}0.792 \\
0.808 \\
0.877 \\
0.765 \\
0.736 \\
0.658 \\
0.686\end{array}$ & 0.876 \\
\hline $\begin{array}{l}\text { Convergence } \\
\text { and } \\
\text { Collaboration }\end{array}$ & $\begin{array}{l}\mathrm{CaC} 4 \\
\mathrm{CaC} 3 \\
\mathrm{CaC} 2 \\
\mathrm{CaC} 1\end{array}$ & $\begin{array}{l}4.486 \\
5.029 \\
4.943 \\
5.014\end{array}$ & $\begin{array}{l}1.7627 \\
1.6559 \\
1.4725 \\
1.8322\end{array}$ & $\begin{array}{l}0.595 \\
0.542 \\
0.772 \\
0.752\end{array}$ & 0.830 & 0.964 & $\begin{array}{l}0.705 \\
0.718 \\
0.764 \\
0.814\end{array}$ & 0.870 \\
\hline $\begin{array}{l}\text { Firm } \\
\text { Performance }\end{array}$ & $\begin{array}{l}\text { FP4 } \\
\text { FP3 } \\
\text { FP2 } \\
\text { FP1 }\end{array}$ & $\begin{array}{l}5.104 \\
5.493 \\
5.270 \\
5.033\end{array}$ & $\begin{array}{l}1.0438 \\
1.1511 \\
1.3224 \\
1.0415\end{array}$ & $\begin{array}{l}0.429 \\
0.757 \\
0.799 \\
0.713\end{array}$ & 0.835 & 0.966 & $\begin{array}{l}0.850 \\
0.856 \\
0.891 \\
0.804\end{array}$ & 0.877 \\
\hline
\end{tabular}

Table 2: Summary of measurement model

\subsection{The structural model}

Structural equation modelling was used to test the investigative framework; the structural model is shown in Figure 2. It was developed using AMOS 17.0. For the model fit indices the methodologies given by Hair et al. [19], Yang \& Su [50], and Williams \& Hazer [49] were used. A total of 142 responses were received, which is acceptable for structural equation modelling $\left(>5^{*}\right.$ no. of distinct parameters, $5 * 27=135$, [19]). The chi-squared statistical significance level of 0.876 is above the minimum level of 0.05 and the more conservative levels of 0.10 or 0.20 . This indicates that the model is a good fit. The normed chi-square $(X$ $2 / \mathrm{df}$ ) has a value of 1.24 . This falls well within the recommended levels of 1.0 to 2.0 [17]. The goodness of fit index (GFI) of 0.997 is also quite high, adjusting for model parsimony; the adjusted goodness of fit index (AGFI) value is 0.974 , which is acceptable. The incremental fit indices - i.e. the Tucker-Lewis index (TLI) and normed fit index (NFI) - are 1.061 and 0.998 respectively and is above the recommended levels of 0.90 , the RMSEA is below the suggested threshold value of 0.08 . Table 3 and Table 4 show the fit indices of the structural model and a comparison of average and square roots correlations respectively. In addition, the discriminant validity of the latent constructs is assessed in two ways. First, as suggested by Anderson \& Gerbing [2], the 99\% confidence intervals around the correlation parameter estimated between all possible pairs of scales, and established that none of these intervals included one. Second, the square of the correlation between any two constructs was less than the average extracted estimates [14]. Overall, these results show an adequate level of reliability and validity. 


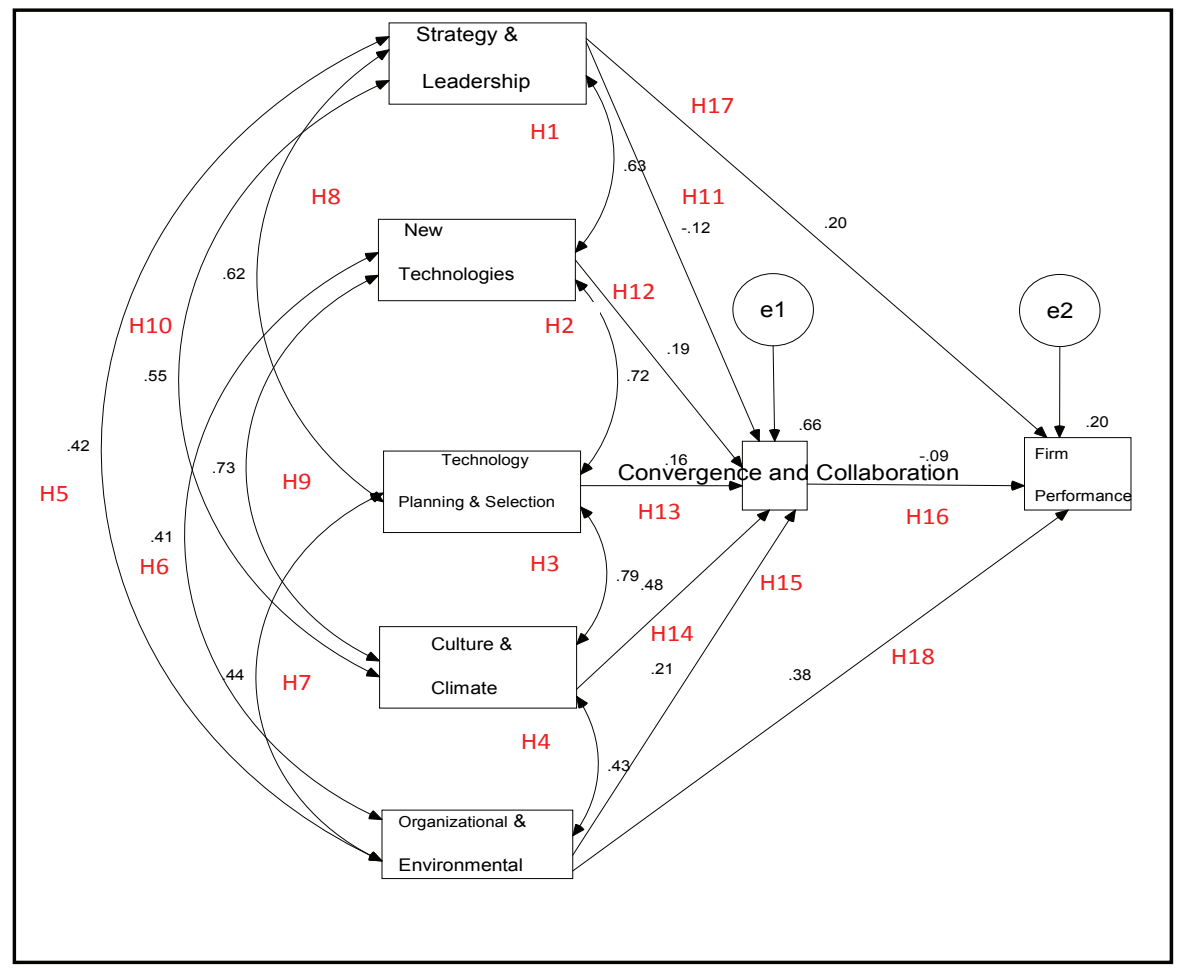

Figure 2: Research results

\begin{tabular}{|l|l|}
\hline Description & Value \\
\hline Chi-Squared & 3.737 \\
df & 3 \\
P value & 0.876 \\
Tucker Lewis Index (TLI) & 1.061 \\
Normed fit index(NFI) & 0.998 \\
Comparative fit index(CFI) & 1.00 \\
GFI & 0.997 \\
AGFI & 0.974 \\
RMR & 0.259 \\
RMSEA & 0.034 \\
\hline
\end{tabular}

Table 3: Fit indices of structural model

\begin{tabular}{|c|c|c|c|c|c|c|c|}
\hline Var & CCLIM & OENV & STLEAD & PSEL & NTECH & CCOLA & FPERF \\
\hline CCLIM & 0.985822 & & & & & & \\
\hline OENV & 0.435 & 0.976216 & & & & & \\
\hline STLEAD & 0.551 & 0.422 & 0.984667 & & & & \\
\hline PSEL & 0.789 & 0.443 & 0.617 & 0.985634 & & & \\
\hline NTECH & 0.732 & 0.41 & 0.634 & 0.716 & 0.990073 & & \\
\hline CCOLA & 0.768 & 0.519 & 0.451 & 0.692 & 0.663 & 0.981979 & \\
\hline FPERF & 0.206 & 0.414 & 0.32 & 0.229 & 0.222 & 0.196 & 0.982922 \\
\hline
\end{tabular}

*The shaded numbers in the diagonal are square roots of the average variance extracted

Table 4: Comparison of average and square root correlations 


\section{DISCUSSION OF RESULTS}

The main objective of this study is to investigate how firms may align technology and business strategy. This alignment may yield better performance, leading to competitive advantage. The two central questions posed have been supported through the research study:

- Does the adoption of new technologies result in changes in a firm's organisational and environmental evolution? This question is supported through the research: hypotheses $\mathrm{H} 1$ to $\mathrm{H} 10$ are all positively correlated, indicating a positive relationship between the adoption of new technologies and a firm's organisational and environmental evolution.

- Do changes in a firm's organisational and environmental evolution lead to improved performance? This question is supported by the research study. Hypothesis $\mathrm{H} 18$ is supported - i.e. organisational and environmental evolution does lead to better performance. Further research is required to understand better the factors driving convergence and collaboration, as none of the related hypotheses $(\mathrm{H} 11, \mathrm{H} 12, \mathrm{H} 13$, and $\mathrm{H} 14$ ) was supported. The only link that could be established was $\mathrm{H} 15$ - i.e. organisational and environmental evolution and convergence and collaboration.

The research results provide a strong overall validation of the investigative framework, with 12 out of 18 hypotheses supported. Based on these results, Table 5 shows the different propositions.

\begin{tabular}{|c|c|c|c|}
\hline Hypothesis & Supported & Not supported & Significance P-value \\
\hline $\mathrm{HI}$ & $\sqrt{ }$ & & $0.63, p<0.001$ \\
\hline $\mathrm{H} 2$ & $\sqrt{ }$ & & $0.72, p<0.001$ \\
\hline $\mathrm{H} 3$ & $\sqrt{ }$ & & $0.79, p<0.001$ \\
\hline $\mathrm{H} 4$ & $\sqrt{ }$ & & $0.43, p<0.001$ \\
\hline H5 & $\sqrt{ }$ & & $0.42, p<0.001$ \\
\hline $\mathrm{H} 6$ & $\sqrt{ }$ & & $0.41, p<0.001$ \\
\hline $\mathrm{H} 7$ & $\sqrt{ }$ & & $0.44, p<0.001$ \\
\hline $\mathrm{H} 8$ & $\sqrt{ }$ & & $0.62, p<0.001$ \\
\hline H9 & $\sqrt{ }$ & & $0.73, p<0.001$ \\
\hline $\mathrm{H} 10$ & $\sqrt{ }$ & & $0.55, p<0.001$ \\
\hline $\mathrm{H} 11$ & & $\sqrt{ }$ & $-0.12, p<0.05$ \\
\hline $\mathrm{H} 12$ & & $\sqrt{ }$ & $0.19, p<0.05$ \\
\hline $\mathrm{H} 13$ & & $\sqrt{ }$ & $0.16, p<0.05$ \\
\hline $\mathrm{H} 14$ & & $\sqrt{ }$ & $0.48, p<0.05$ \\
\hline $\mathrm{H} 15$ & $\sqrt{ }$ & & $0.21, p<0.001$ \\
\hline $\mathrm{H} 16$ & & $\sqrt{ }$ & $-0.09, p<0.05$ \\
\hline $\mathrm{H} 17$ & & $\sqrt{ }$ & $0.20 ; p<0.05$ \\
\hline $\mathrm{H} 18$ & $\sqrt{ }$ & & $0.38, p<0.01$ \\
\hline
\end{tabular}

Table 5: Summary of hypotheses 
Apart from organisational and environmental evolution, none of the links to convergence and collaboration could be established. It is proposed that further research be conducted to establish links to convergence and collaboration. Possible areas for links may lie in relationship management, organisational learning, and technology sourcing.

From this study it is evident the strategic alignment of business needs and technology requirements may lead to improvements in a firm's organisational and environmental evolution. This effect on organisational and environmental evolution positively impacts convergence and collaboration and performance.

\section{LIMITATIONS OF RESEARCH}

While the study looked at firms in the electronics and electrical, information and communication technology, fast moving consumer goods (FMCG), logistics, and financial industries, the research could be extended to look at relationships between the different sectors. This is largely limited by the sample size. The research could also be expanded to other countries. Other factors driving organisational and environmental evolution - such as relationship management, organisational learning, and technology sourcing - could also be included in the investigative framework.

\section{FURTHER RESEARCH}

Further research may involve the following:

- $\quad$ Comparing the relationships between different industry sectors.

- $\quad$ Expanding the research to include other countries, and comparing the differences between countries.

- Investigating other drivers for convergence and collaboration that may lead to links to performance. These links may include relationship management, organisational learning, and technology sourcing.

\section{CONCLUSION}

The research looked at the strategy and adoption of new technologies, and its impact on a firm's performance. However, when Likert scales are used, one needs to be aware that they reflect only the attitude of individuals, and therefore in this case they serve as an indication of the respondent's attitudes regarding the adoption of technology. The linkages formed in the SEM are thus a reflection of the attitudes/perceptions of the respondents. Further research is required to form more robust claims about the actual contribution of technology. Proof of the actual contribution of technology needs to be seen in terms of operational benefits. To this end, case study analysis of real cases needs to be conducted. However, firms may be unwilling to disclosure actual data, and so case study research may be difficult to conduct.

From this research using SEM, several linkages were found between a firm's performance and new technology adoption. The links supported are shown in Table 5, with 12 out of 18 hypotheses being supported. Further research is required to test the actual contribution of new technologies to convergence and collaboration. Of the five possible links to convergence and collaboration, only one - organisational and environmental evolution - was supported. More research is required in this area.

The two central questions to be answered are:

- Does new technology adoption lead to changes in the firm's organisational and environmental evolution? Links from strategy, technology adoption, technology planning and selection, culture and climate, and the firm's organisational and environmental evolution could be established. 
Do changes in the firm's organisational and environmental evolution lead to improvements in performance? Links from the firm's organisational and environmental evolution could be established.

Using the model developed in this research, several hypotheses were formed. We may conclude that through the correct strategic alignment, new technology adoption affects factors like culture and climate and a firm's organisational and environmental evolution. These factors indirectly lead to better performance, which may lead to competitive advantage.

\section{REFERENCES}

[1] Armstrong, J.S. \& Overton, T.S. 1997. Estimating non-response bias in mail surveys. Journal of Marketing Research, 14(3), pp. 61-83.

[2] Anderson, J.C. \& Gerbing, D.W. 1988. Structural equation modeling in practice: A review and recommended two-step approach. Psychological Bulletin, 103 (3), pp. 411-423.

[3] Birchall, D.W., Chanaron, J.J. \& Soderquist, K. 1996. Managing innovation in SMEs: A comparison of companies in the UK, France and Portugal, International Journal of Technology Management, 12(3), pp. 291-305.

[4] Bharadwaj, A.S. (2000). A resource-based perspective on information technology capability and firm performance: A resource-based study, MIS Quarterly, 24, 1, pp. 169-196.

[5] Boyer, K.K., Ward, P.T. \& Leong, G.K. 1996. Approaches to the factory of the future: An empirical taxonomy, Journal of Operations Management, 14, pp. 297-313.

[6] Burgelman, R.A., Christensen, C.M. \& Wheelwright, S.C. 2009. Integrating technology and strategy: A general management perspective, in Strategic Management of Technology and Innovation, $5^{\text {th }}$ edition.

[7] Carr, A.S. \& Pearson, J.N. 1999. Strategically managed buyer-supplier relationships and performance outcomes, Journal of Operations Management, 17, pp. 497-519.

[8] Cetindamar, D. \& Phaal, R. 2009. Understanding technology management as a dynamic capability: A framework for technology management activities, Technovation, 29, pp. 237-246.

[9] Chesbrough, H. 2003. Open-innovation. Harvard Business School Press, Boston, MA.

[10] Cormican, K. \& O'Sullivan, D. 2004. Auditing best practice for effective product innovation management, Technovation, 24, pp. 819-829.

[11] Day, G.G., Schoemaker, P.J.H. \& Gunther, R.E. 2000. Managing emerging technologies, Wiley.

[12] Da Silveira, G. 2001. Innovation diffusion: Research agenda for developing economies, Technovation, 21, pp. 767-773.

[13] Drejer, A. 1996. Frameworks for the management of technology: Towards a contingent approach, Technology Analysis and Strategic Management, 8 (1), pp. 920.

[14] Fornell, C. \& Larker, D.F. 1981. Evaluating structural equation models with unobservable variables and measurement error. Journal of Marketing Research, 18(1), pp. 39-50.

[15] Freel, M. 2000. Barriers to product innovation in small manufacturing firms. International Small Business Journal, 18 (2), pp. 60-73.

[16] Friedman, T.L. 2006. The world is flat, Penguin Books.

[17] Gomes-Casseres, B. 1997. Alliances strategies of small firms, Small Business Economics, 9, pp. 33-44.

[18] Gupta, M., Czernik, A. \& Sharma, R.D. 2001. Operations strategies of banks using new technologies for competitive advantage, Technovation, 21, pp. 775-782.

[19] Hair, J.F. Jr., Anderson, R.E., Tatham, R.L. \& Black, W.C. 1998. Multivariate data analysis, Prentice Hall, $5^{\text {th }}$ edition.

[20] Hamel., G. 2000. Leading the revolution, Harvard Business School Press.

[21] Hanna-Kisa, E., Wikstrom, P. \& Jantunen, A. Linking dynamic-capability portfolios and innovation outcomes, Technovation, 29, pp. 753-762. 
[22] Henderson, J.C. \& Venkatraman, N. 1993. Strategic alignment: Leveraging information technology for transforming organisations. IBM Systems Journal, 32, 1, 4-16.

[23] Janszen, F. 2000. The age of innovation, Prentice Hall.

[24] Ismail, H.S., Snowden, S.P., Poolton, J., Reid, I.R. \& Arokiam, I.C. 2006. Agile manufacturing framework and practice, International Journal of Agile Systems and Management 1 (1), pp. 11-28.

[25] Kaufmann, A. \& Todtling, F. 2002. How effective is innovation support for SMEs? An analysis of the region of upper Austria. Technovation 22, pp. 147-159.

[26] Kohler, T., Matzler, K. \& Fuller, J. 2009. Avatar-based innovation: Using virtual worlds for real-world innovation, Technovation, 29, pp. 395-407.

[27] Kettunen, P. 2008. Adopting key lessons from agile manufacturing to agile software product development - A comparative study, Technovation, 29, pp.408-422.

[28] Lin, I. 2004. Innovation in the networked world: New corporate mindsets for the cyber age, in Barker, C. \& Coy, R., Innovation and imagination at work, $2^{\text {nd }}$ edition, McGraw Hill Australia.

[29] Linton, J. 2009. De-babelizing the language of innovation, Technovation, 29, pp. 729-737.

[30] Luftmann, J.N., Lewis, P.R. \& Oldach, S.H. 1993. Transforming the enterprise: The alignment of business and information technology strategies, IBM Systems Journal, $32,1,198-221$.

[31] Mazzarol, T. \& Rebound, S. 2008. The role of complementary actors in the development of innovation in small firms, International Journal of Innovation Management, 12 (2), pp. 223-253.

[32] Mitarai, F. 2004. The Canon way of growth innovation is the name of the game, in Business Week, European Edition, 75 Anniversary Issue, October 11, pp. 14-15.

[33] Nelson, R.S. 1991. Why do firms differ, and how does it matter? Strategic Management Journal, 12, pp. 61-74.

[34] Parthasarthy, R. \& Sethi, S.P. 1992. The impact of flexible automation on business strategy and organizational structure. Academy of Management Review 17 (1), pp. 86-111.

[35] Porter, M.E. 1990. The competitive advantage of nations, $2^{\text {nd }}$ edition, MacMillan.

[36] Porter, M.E. 1991. Towards a dynamic theory of strategy, Strategic management Journal, 12, pp. 95-117.

[37] Porter, M.E. 1996. What is a strategy? Harvard Business Review, NovemberDecember 1996, in Burgelam, R.A., Christensen, C.M., Wheelwright, S.C., Strategic Management of Technology and Innovation, McGraw-Hill.

[38] Radas, S. \& Bozic, L. 2009. The antecedents of SME innovativeness in an emerging transition economy, Technovation, 29, pp. 438-450.

[39] Ross, J.W. \& Beath, C.M. 2002. Beyond the business case: New approaches to IT investment, MIT Sloan Management Review, Winter, pp. 51-59.

[40] Salhieh, Sa'Ed. M. 2007. A systematic approach for selection of business processes for E-enablement. International Journal of Information Technology and Decision Making, 6 (4), pp. 649-669.

[41] Sams, S. 2005. Emerging expertise, Harvard Business Review, May, reprint F0505F, pp. $1-3$.

[42] Shapiro, S.M. 2002. 24/7 Innovation, McGraw Hill.

[43] Siriram, R. \& Snaddon, D.R. 2004. Verifying links in technology management, transaction processes and governance structures, Technovation, 25, pp. 321-337.

[44] Stoneman, P. \& Kwon, M.J. 1996. Technology adoption and firm profitability, The Economic Journal, 106, 952-962.

[45] Teece, D.J. 2007. Explicating dynamic capabilities: The nature and microfoundations of (sustainable) enterprise performance. Strategic Management Journal, 28, pp. 1319-1350.

[46] Teece, D.J., Pisano, G. \& Sheun A. 1997. Dynamic capabilities and strategic management, Strategic Management Journal, 18, pp. 509-533.

[47] Urstadt, B. 2006. A tangle of wires. Technology review, an MIT Enterprise, December 2005/January 2006, pp. 1-3. 
[48] Van de Vrande, V.J.A., De Jong, J.P.J. \& Vanhaverbeke, W. 2009. Open Innovation in SMEs: Trends, motives and management challenges, Technovation, 29, pp. 423-437.

[49] Williams, L.J. \& Hazer, J.T. 1986. Antecedents and consequences of satisfaction and commitment in turnover models: A reanalysis using latent variable structural equation models, Journal of Applied Psychology, 71(2), pp. 219-231.

[50] Yang, C. \& Su, Yi-fen. 2008. The impact of ERP implementation on corporate SCM performance: From an operational and information integration perspective, Proceedings of the 2008 IEEE IEEM Conference, pp. 1668-1672.

[51] Zahra, S.A. \& Covin, J.G. 1993. Business strategy, technology policy and firm performance, Strategic Management Journal, 14 (6), pp. 451-478. 
